\title{
СОВЕРШЕНСТВОВАНИЕ УЧЕТА КАК ИНСТРУМЕНТ ОБЕСПЕЧЕНИЯ ИСПОЛНЕНИЯ ОБЯЗАТЕЛЬСТВ ХОЗЯЙСТВУЮЩИМИ СУБЪЕКТАМИ
}

\author{
(c) 2018 Егорова Лариса Владимировна \\ доктор экономических наук, профессор кафедры «Экономика» \\ Российский новый университет \\ 105005, Москва, улица Радио, 22
}

\begin{abstract}
Статья посвящена совершенствованию бухгалтерского и налогового учета с целью обеспечения эффективности взыскания обязательных платежей в бюджет и в пользу контрагентов при процедурах банкротства хозяйствующих субъектов. В данной статье автор изложила результаты очередного этапа исследования по вопросу оптимизации и повышении эффективности взыскания долговых обязательств перед кредиторами различных уровней, в том числе налоговых и неналоговых платежей при процедуре банкротства. Актуальность темы исследования обусловлена тем, что, несмотря на постепенную ликвидацию нормативных пробелов в области формирования конкурсной массы при процедуре банкротства, по-прежнему остаются проблемные моменты. Предметом исследования выступают взаимоотношения хозяйствующего субъекта с контрагентами, налоговыми органами, кредиторами по вопросу погашения обязательств на фоне сложной финансовой ситуации, предкризисного и кризисного состояния, при проведении процедуры банкротства. Объект - возможные пути повышения качества бухгалтерского и налогового учета с целью управления дебиторской задолженностью как одного из инструментов погашения обязательств. Теоретико-методологической базой исследования выступили нормативно-законодательные акты, материалы судебных и арбитражных процессов, труды отечественных специалистов. Практическое значение исследования заключается в предложениях по возможным путям совершенствования учета дебиторской задолженности.
\end{abstract}

Ключевые слова: налоговые и неналоговые обязательства, банкротство, бухгалтерский учет, налоговый учет, обязательные платежи, дебиторская задолженность.

Как представляется автору данной статьи, продолжающаяся в нашей стране налоговая реформа требует совершенствования различных видов учета (финансового, налогового, управленческого учета), которые позволят повысить эффективность налоговых преобразований. В современных условиях хозяйствования топ-менеджмент заинтересован в грамотной организации бухгалтерского и налогового учета, поскольку от этого во многом зависит финансовое положение организации. Естественно, что руководители и бухгалтеры стремятся к максимальному сближению обоих видов учета с целью снижения трудозатрат. Кроме того, возможность комбинирования бухгалтерского и налогового учета для целей налогового планирования и оптимизации налогообложения дает возможность организации вести постоянный мониторинг налоговых обязательств и путем их сокращения, позволяет законным способом минимизировать налоговую базу, а, как следствие, и суммы налоговых платежей.

Особенно актуальна проблема своевремен- ного и полного погашения налоговых и неналоговых обязательств при наступлении сложной ситуации для каждого субъекта в виде банкротства. Эта ситуация обоюдоострая для самой организации в частности, так и государства, в целом. Хозяйствующий субъект, оказавшийся в сложной финансовой ситуации должен, тем не менее, погасить свои обязательства, чтобы государственный бюджет не потерял средства, формирующие его. Банкротство (несостоятельность) регулируется Ф3 № 127-Ф3 «О несостоятельности (банкротстве)» и включает в себя несколько разных процедур [2]. При этом, только одна из процедур ведет к ликвидации должника - конкурсное производство, применяемое к действующему хозяйствующему субъекту в случае безнадежного финансового состояния, и отсутствия реальной возможности восстановить его платежеспособность. Как известно, конкурсное производство - заключительный этап процедуры банкротства, при котором на этапе реализации имущества конкурсный управляющий занимается формированием конкурсной массы. 
Под конкурсной массой понимается все имущество должника, которое принадлежало ему или было выявлено в ходе конкурсного производства, на которое позволяется наложить взыскание. Чем больше конкурсная масса, тем выше вероятность того, что кредиторы получат свои средства в полном объеме.

Арбитражный управляющий производит формирование и оценку собственности должника на основании данных бухгалтерской отчетности. В конкурсную массу попадает все имущество, которое может быть использовано для возврата денег кредиторам. Немаловажным источником погашения обязательств при конкурсном производстве является дебиторская задолженность должника. Аналитики всегда подчеркивают, что у любого хозяйствующего субъекта для обеспечения нормальной финансовой устойчивости, ликвидности и платежеспособности в идеальном варианте кредиторская и дебиторская задолженности должны быть примерно равны. То есть когда возникает предкризисная ситуация и не хватает оборотных средств для погашения налоговых и неналоговых обязательств организации, она должна иметь возможность их полного или частичного погашения за счет поступлений от дебиторов.

Взыскание задолженности с контрагентов осуществляется как в досудебном порядке (путем проведения переговоров либо направления претензий), так и в суде. Статья 132 ГК РФ определяет отличие дебиторской задолженности от другого имущества должника [1]. Эта особенность заключается том, что дебиторская задолженность не имеет функции товара, а, следовательно, продаваться может только уступка права требования посредством факторинга. При процедуре конкурсного производства априори вся дебиторская задолженность является просроченной и оценивается только с точки ее возможной продажи по рыночной стоимости.

Один из инструментов обеспечения исполнения налоговых обязательств для субъектов любых организационно - правовых форм, это эффективное управление дебиторской задолженностью. Нет сомнений в том, что этой задолженностью необходимо грамотно управлять с целью оптимизации ее общей величины и обеспечения ее своевременного погашения, что позволяет получить дополнительные оборотные средства для погашения налоговых обязательств. Хозяйствующим субъектам необходимо разра- ботать грамотную кредитную политику, которая позволит контролировать долю дебиторской задолженности в общей структуре активов, а также снизить риск возникновения безнадежной дебиторской задолженности [3]. Среди имеющихся способов решения данной проблемы наиболее реальными к исполнению являются следующие:

Во - первых, автоматизация процесса учета задолженности, с целью внедрения единой базы данных по всему хозяйствующему субъекту, что намного упростит рассмотрение состояния расчетов с контрагентами. В электронной карточке контрагента обязательно должны быть отражены установленные сроки наступления платежа, период возникновения задолженности, договорные условия. Удобно такую карточку делать в программе Excel, чтобы иметь возможность быстро рассчитывать суммы штрафов и пеней при наступлении просрочки платежа. Во - вторых, необходимо осуществлять процесс ежедневной работы с контрагентами, как исполняющими свои обязательства в установленные договором сроки, так и с недобросовестными должниками. В - третьих, обязательно предусматривать в договорах с контрагентами ответственность в виде штрафов и пеней за просрочку платежей, возможно с применением прогрессирующей ставки пени при длительных неплатежах.

Необходимо акцентировать внимание на том, что основными пользователями программы по учету дебиторской задолженности являются: 1) специалисты и руководители отдела сбыта (контроль и востребование дебиторской задолженности); 2) специалисты юридической службы (взыскание проблемных долгов с контрагентов); 3) топ менеджмент компании (анализ причин невозврата долгов, принятие управленческих решений); 4) бухгалтерская служба (контроль сроков оплаты дебиторской задолженности, ее востребование и учет).

Слаженное взаимодействие подразделений, участвующих в процессе управления дебиторской задолженностью, и функции сотрудников является залогом успешной работы по ее возврату. Поэтому процесс контроля и взыскания дебиторской задолженности должен быть строго регламентирован, а прогнозирование и мониторинг платежеспособности контрагентов должны стать беспрерывным действием [3].

Для повышения эффективности работы сотрудников, осуществляющих востребование дебиторской задолженности, можно рекомен- 
довать руководству хозяйствующего субъекта мотивировать их премиями или повышающими коэффициентами к зарплате, в зависимости от уровня востребованной дебиторской задолженности или от соблюдения сроков ее погашения. Так же, организации, при реализации товаров, работ (услуг) с отсрочкой платежа, необходимо определить для себя размер риска, который оно готово понести в случае неоплаты. Поэтому, политика предоставления отсрочек платежа должна быть направлена на исключение из числа партнеров организаций-дебиторов с высоким уровнем риска.

В зависимости от размера коммерческого кредита руководитель хозяйствующего субъекта собирает вполне определенную, детализированную информацию. Ее основные источники: 1) внутренняя информация относительно поведения контрагента в прошлом; 2) внешняя информация, предоставленная специализированными агентствами, и т.п. И только после изучения финансового состояния и репутации контрагентов, а также их значимости (незначительный, крупный) для хозяйствующего субъекта руководитель может принять соответствующее решение.

Возвращаясь к проблеме погашения обязательств хозяйствующих субъектов, имеющих в активах большие объемы дебиторской задолженности, при реализации в отношении них процедуры банкротства, следует обратить внимание на следующее. Арбитражным управляющим необходимо оптимизировать расходы на процедуры банкротства, принять меры по завершению процедур банкротства должников, конкурсное производство в отношении которых длится более двух лет.

Помимо вышеизложенного, можно отметить, что до текущего момента много нерешенных проблем в самом законодательстве о банкротстве, связанных с процедурой погашения налоговых и неналоговых обязательств. Для решения этих проблем можно привести потенциальные пути их решения, отраженные в прежних исследованиях автора и других специалистов: 1) необходимо повысить ответственность за несвоевременное обращение должника с заявлением о банкротстве; 2) необходимо увеличить размер штрафных санкций административной ответственности в отношении учредителей должника фирм «однодневок»; 3) внести изменения в порядок утверждения арбитражного управляю- щего в зависимости от качества исполнения им своих обязанностей; 4) изменить порядок финансирования расходов по делу о банкротстве с учетом действительной стоимости активов и связать ее с обоснованностью расходов на оплату услуг привлеченных специалистов [4].

Еще одной проблемой при исполнении обязательств при процедуре несостоятельности может стать истребование имущества из чужого незаконного владения. Сложность заключается в том, что не всегда принадлежащее должнику имущество фактически находится в его руках. На основании письменных или устных договоренностей оно может быть: 1) передано частично в пользование контрагентам; 2) выведено из владения по недействительным сделкам; 3) выведено в результате мошеннических действий третьих лиц или силового давления.

При возникновении подобных ситуаций, имущество должно быть возвращено и включено в конкурсную массу. Кроме того, банкротство дает возможность оспорить и отменить незаконные сделки (купли-продажи, займа, залога, взаимозачетов и пр.) должника с целью включения его в конкурсную массу для расчетов по обязательствам. Однако, чтобы было выполнено это включение необходимо, чтобы суд признал сделку недействительной или ничтожной. Подобное признание возможно, если:

- сделка имеет признаки заинтересованности;

- совершением сделки был причинен существенный имущественный ущерб фирме-должнику или контрагенту;

- сделка была совершена с заниженной стоимостью активов и по прочим законодательно установленным основаниям.

После того, как конкурсная масса сформирована, активы реализуются и средства распределяются по требованиям кредиторов в порядке законодательно предусмотренной очередности. Сначала - по текущим платежам, затем - выплаты лицам, которым причинен вред здоровью, заработная плата работникам, и только потом удовлетворяются требования остальных, реестровых, кредиторов.

Существенным моментом в процедуре банкротства является передача первичной документации бывшим руководством организации - должника конкурному управляющему. Не позднее 3 дней с момента открытия конкурсного производства директор обеспечивает переда- 
чу печатей, штампов, товарно - материальных ценностей, бухгалтерской и иной документации. На этом этапе очень важным является качество бухгалтерской документации, точность, полнота и достоверность бухгалтерской отчетности. Если первичные учетные документы, внутренняя отчетность хозяйствующего субъекта, сформированная в управленческом учете и отчетность, скомпонованная в сфере финансового учета, содержат недочеты, ошибки, искажения, то это может повлечь образование различных задолженностей и к уплате доначисленных налогов и сборов. Особую роль в этой ситуации играет внутренняя отчетность, сформированная в управленческом учете хозяйствующего субъекта, поскольку содержит информацию о себестоимости продукции (товаров, работ, услуг), непосредственно влияющую на формирование финансового результата.

Однако, как показывает арбитражная практика, в большинстве случае, бухгалтерская отчетность не предается, налоговая отчетность не сдается, управленческий учет не ведется. А ведь грамотное управление предполагает обязатель- ный учет просроченных обязательств - дебиторской и кредиторской задолженности. Управление этими видами обязательств является важным фактором для обеспечения финансовой стабильности хозяйствующего субъекта, а определение долга включает в себя факторы, при которых он образуется. Увеличение долга, а как следствие неспособность организации отвечать по денежным обязательствам перед кредиторами является причиной банкротства организации - должника. Не переданные сведения и документы о дебиторской задолженности должника, тем самым создают препятствия для ее взыскания и включения вырученных средств в конкурсную массу.

Таким образом, для обеспечения эффективного исполнения обязательств по налоговым и неналоговым платежам при процедуре несостоятельности, следует действовать одновременно в двух направлениях: совершенствования законодательства об ответственности арбитражных управляющих и повышения качества бухгалтерского учета, особенно в части работы с дебиторской задолженностью хозяйствующего субъекта.

\section{Библиографический список}

1. Гражданский кодекс РФ (с комментариями) // СПС Гарант, 2018.

2. Федеральный закон 127-ФЗ от 26.10.2002 «О несостоятельности (банкротстве) с изменениями и дополнениями // СПС Гарант, 2018.

3. Исаченко М.Б. Управление дебиторской задолженностью и разработка кредитной политики // Успехи современного естествознания. № 12, 2016.

4. Егорова Л.В., Косарцова И. Роль налогового и управленческого учета в системе принципов эффективности взыскания налоговых обязательств в рамках обеспечения процедур банкротства // Вестник ИЭАУ- электронный периодический журнал, № 162017 г. http://www/ieay.ru/ assets/ fiels/vestnik/16/kosarcova-egoroval.v. pdf) 